\title{
PENGARUH MULSA DAN PUPUK KANDANG SAPI TERHADAP PERTUMBUHAN DAN HASIL TANAMAN KEDELAI (Glycine max (L.) Merril) PADA LAHAN PASANG SURUT
}

\author{
Desi Mariana Sari ${ }^{1}$, La Sarido ${ }^{2}$, Rudi $^{2}$ \\ ${ }^{1}$ Program Studi Agroteknologi, Sekolah Tinggi Pertanian Kutai Timur, Sangatta, Indonesia. \\ Alamat: Jalan Sukarno-Hatta No.1 Sangatta, Kabupaten Kutai Timur, Kaltim, Indonesia \\ ${ }^{2}$ Dosen Program Studi Agroteknologi, Sekolah Tinggi Pertanian Kutai Timur, Sangatta, \\ Indonesia. \\ E-Mail: rudin.sangatta@gmail.com
}

\begin{abstract}
ABSTRAK
Pengaruh Mulsa dan Pupuk Kandang Sapi Terhadap Pertumbuhan dan Hasil Tanaman Kedelai (Glycine max (L.) Merril) Pada Lahan Pasang Surut. Tujuan penelitian adalah untuk : (1) Mengetahui pengaruh mulsa dan pupuk kandang sapi terhadap pertumbuhan dan hasil tanaman kedelai dilahan pasang surut, (2) Mengetahui dosis pupuk kandang sapi yang terbaik terhadap hasil tanaman kedelai dilahan pasang surut, (3) Mengetahui ketebalan mulsa yang terbaik untuk tanaman kedelai dilahan pasang surut.

Penelitian ini dilaksanakan pada bulan Maret 2018 sampai Juni 2018. Tempat penelitian Di Jalan A Wahab Syahranie, Sangatta Utara, Kutai Timur. Rancangan yang digunakan adalah Rancangan Acak Kelompok (RAK) faktorial dengan 3 taraf perlakuan pemberian mulsa dan 3 perlakuan pemberian pupuk kandang sapi sehingga diperoleh 9 kombinasi. Masing-masing perlakuan dikelompokkan sebanyak 3 kali. Taraf perlakuan yaitu faktor pertama perlakuan mulsa (M0) Tanpa mulsa, (M1) Mulsa jerami ketebalan $2 \mathrm{~cm}$, (M2) Mulsa jerami ketebalan $4 \mathrm{~cm}$, faktor kedua pupuk kandang sapi (S0) Tanpa Pupuk kandang sapi, (S1) Perlakuan pupuk kandang sapi $4 \mathrm{~kg} /$ petak, (S2) Perlakuan pupuk kandang sapi $6 \mathrm{~kg} /$ petak. Untuk mengetahui pengaruh perlakuan maka dianalisis dengan sidik ragam Uji F 5\% dan 1\% dan bila terdapat hasil berbeda nyata maka dilanjutkan dengan uji BNT 5\%.

Hasil penelitian menunjukkan Pengaruh Mulsa berbeda nyata terhadap parameter tinggi tanaman 7 hst, 14 hst, 21 hst, jumlah cabang umur 14 hst, 21 hst, dan umur panen. Sedangkan pengaruh pupuk kandang berbeda nyata terhadap jumlah cabang 14 hst, 21 hst, dan umur panen. Pemberian mulsa $4 \mathrm{~cm}$ dan pupuk kandang sapi $6 \mathrm{~kg} /$ petak menunjukkan hasil terbaik.
\end{abstract}

Kata kunci : Kedelai, Mulsa, Pupuk kandang.

\begin{abstract}
The effect of mulch and manure on the yield of soybean plants (Glycine max (L.) Merril) on tidal land. The research objectives werw to : (1) Knowing the effect of mulch and cow manure on the growth and yield of soybean plants in tidal, (2) Find out the best dosage of cow manure on the yield of soybean in tidal, (3) Find out best thickness of mulch for soybean plants in tidal.

This research was conducted in March 2018 to June 2018. The place of research was on the road A Wahab Syahranie, Sangatta Utara, Kutai Timur. The design used was factorial randomized block design (RBD) with 3 levels of treatment of giving mulch and 3 treatments for giving cow manure so obtained 9 cobination. Each treatment was grouped 3 times. The level of treatment was the first factor of mulch, (M0) without mulch, (M1) straw mulch with a thickness of $2 \mathrm{~cm}$, (M2) straw mulch with a thickness of $4 \mathrm{~cm}$, the second factor was cow manure (SO) without cow manure, (S1) Treatment of cow manure $4 \mathrm{~kg} / \mathrm{plot}$, (S2) treatment of $6 \mathrm{~kg}$ cow manure/plot. To determine the effect of the treatment, it was analyzed with a $5 \%$ and $1 \%$ of the $F$ test variance and if there were significantly different results then followed by a 5\% BNT test.

The results showed the effect of mulch was significantly different on the parameters of plant height 7 days after planting, 14 days after planting, 21 days after planting, number of branches aged 14 days after planting, 21 days after planting, and age of harvest. While the effect of manure significantly different to the number of branches to 14 days after planting, 21 days after planting, and age of harvest. Giving $4 \mathrm{~cm} \mathrm{muls}$ and $6 \mathrm{~kg} / \mathrm{plot}$ showed the best results.
\end{abstract}

Key words : Manure, Mulch, soy. 


\section{PENDAHULUAN}

Kedelai (Glycine max (L.) Merrill) adalah salah satu tanaman polongpolongan dan merupakan sumber utama protein dan minyak nabati utama dunia. Kedelai merupakan tanaman pangan utama strategis terpenting setelah padi dan jagung. Konsumsi kedelai oleh masyarakat Indonesia dipastikan akan terus meningkatkan setiap tahunnya mengingat beberapa pertimbangan seperti bertambahnya populasi penduduk, peningkatan pendapatan per kapita, kesadaran masyarakat akan gizi makanan.

Produksi kedelai di Indonesia pada tahun 2013 diperkirakan 847.16 ribu ton biji kering atau mengalami peningkatan sebesar 4.00 ribu ton $(0.47 \%)$ dibandingkan tahun 2012 dengan produksi sebesar 843.15 ribu ton biji kering, namun produktivitas diperkirakan mengalami penurunan sebesar 0.03 kwintal/hektar (0.20\%) (BPS 2013). Menurut data Kementerian Perdagangan RI, konsumsi kedelai di Indonesia sebesar 2.25 juta ton/tahun dan kekurangan pasokan kedelai diperoleh dengan melakukan impor dari Amerika Serikat (Nugrayasa 2013).

Pupuk organik merupakan pupuk dengan bahan dasar yang diambil dari alam dengan jumlah dan unsur hara yang bervariasi. Penggunaan pupuk organik dapat meningkatkan efisiensi pemakaian pupuk anorganik, karena pupuk organik tersebut dapat meningkatkan air dan hara di dalam tanah, meningkatkan aktivitas mikroorganisme, mempertinggi kadar humus dan memperbaiki struktur tanah (Musnawar, 2005).

Mulsa adalah bahan atau material yang digunakan untuk menutupi permukaan tanah atau lahan pertanian dengan maksud dan tujuan tertntu. Penggunaan mulsa dapat memberikan keuntungan antara lain menghemat penggunaan air dengan mengurangi laju evaporasi dari permukaan lahan, memperkecil fluktuasi suhu tanah sehingga menguntungkan pertumbuhan akar dan mikroorganisme tanah, memperkecil laju erosi tanah baik akibat tumbukan butir-butir hujan maupun aliran permukaan dan menghambat laju pertumbuhan gulma (Lakitan, 1995).

Tujuan penelitian adalah ; Mengetahui pengaruh pemberian mulsa dan pupuk kandang sapi pada pertumbuhan tanaman kedelai dilahan pasang surut, Mengetahui dosis pupuk kandang sapi yang terbaik terhadap hasil tanaman kedelai dilahan pasang surut, Mengetahui ketebalan mulsa yang terbaik untuk tanaman kedelai di lahan pasang surut.

\section{METODA PENELITIAN}

\subsection{Tempat dan Waktu}

Penelitian bertempat di Jalan A Wahab Syahranie, Kecamatan Sangatta Utara, Kabupaten Kutai Timur. Pada bulan Maret-Juni 2018.

\subsection{Bahan dan Alat}

Alat yang digunakan dalam penelitian yaitu: cangkul, ember, parang, timbangan, meteran, kamera, papan plang, penggaris, dan alat tulis. Sendangkan bahan yang digunakan dalam penelitian ini yaitu bibit kacang kedelai varietas anjasmoro, pupuk kandang sapi, dan mulsa jerami padi.

\subsection{Rancangan Penelitian}

Penelitian ini menggunakan Rancangan Acak Kelompok (RAK) dengan 3 taraf perlakuan pemberian mulsa dan 3 perlakuan pemberian pupuk kandang sapi sehingga diperoleh 9 kombinasi perlakuan. Masing-masing perlakuan dikelompokkan sebanyak 3 kali , sehingga terdepat 27 petak penelitian. 
dari:

Adapun faktor perlakuannya terdiri

Faktor pertama adalah perlakuan mulsa

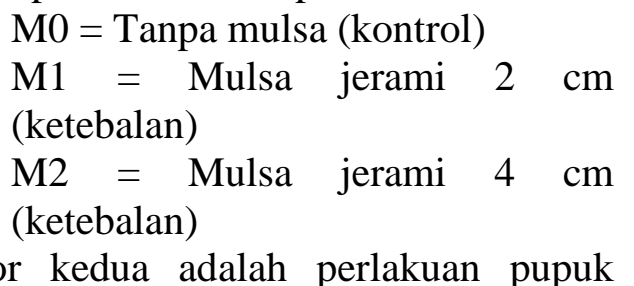

Faktor kedua adalah perlakuan pupuk kandang sapi

S0 = Tanpa pupuk kandang sapi (kontrol)

$\mathrm{S} 1=$ Pupuk kandang sapi 4 $\mathrm{kg} /$ petak (20 t/ha)

$\mathrm{S} 2=$ Pupuk kandang sapi 6 $\mathrm{kg} /$ petak (30 t/ha)

\subsection{Prosedur Penelitian}

a. Persiapan lahan, Persiapan lahan dimulai dengan menentukan luas lahan yang kita gunakan dan membuat bedengan yang kita perlukan. Lalu membuat petakan serta pemasangan label di setiap petaknya.

b. Persiapan benih, Benih yang kita gunakan sebaiknya direndam dalam air untuk memastikan bahwa benih yang kita gunakan itu adalah benih terbaik dan memilah benih yang sempurna untuk di tanam.

c. Penanaman, Penanaman dilakukan dengan sistem tugal sebanyak 3 biji/lubang.

d. Pemberian pupuk kandang sapi dan mulsa jerami padi, jarak tanam yang digunakan $40 \times 20$ $\mathrm{cm}$. Pemberian pupuk kandang dilakukan seminggu sebelum penanaman, kemudian pengaplikasian mulsa dilakukan pada saat tanaman tumbuh umur 7 HST.

e. Pemeliharaan, Pemeliharaan meliputi penyiangan gulma dilakuan sebelum pemberian mulsa dan ketika gulma mulai banyak. Penyiraman dilakuan pada pagi dan sore hari, apabila hujan tanaman tidak di siram.

f. Pemanenan, Panen dilakukan bila polong berwarna kecoklatan dan pecah-pecah serta daun sudah banyak yang kering.

\subsection{Parameter Pengamatan}

a. Tinggi tanaman pada umur 7,14 dan 21 HST.

b. Jumlah cabang pada umur 7,14 , 21 HST.

c. Umur berbunga ditentukan setelah tanaman mulai mengeluarkan bunga.

d. Umur panen (HST)

e. Jumlah polong isi (polong)

f. Berat biji/petak (kg)

g. Produktifitas Tanaman (ton/ha)

\subsection{Data dan Metode Analisis}

Data yang diperoleh dari hasil pengamatan dimasukkan ke dalam tabel pengamatan sedangkan hasil perhitungan dimasukkan ke dalam tabel analisis sidik ragam. Jika $\mathrm{F}$ hitung lebih besar dari $\mathrm{F}$ tabel $1 \%$ maka dilakukan uji lanjutan dengan uji BNT pada taraf $5 \%$.

\section{HASIL PENELITIAN DAN PEMBAHASAN}

\subsection{Tinggi Tanaman Kacang Kedelai (Cm)}

3.1.1.Tinggi Tanaman Umur 7 Hari Setelah Tanam (HST)

Hasil sidik ragam pengaruh pemberian mulsa (M) dengan pupuk kandang sapi (S) serta interaksi kedua perlakuan berbeda tidak nyata terhadap rata-rata tinggi tanaman kedelai umur 7 hari setelah tanam Tabel 2 . 
Tabel 2. Pengaruh Pemberian Mulsa dan Pupuk Kandang Sapi Terhadap Rata-rata Tinggi Tanaman Kacang Kedelai Umur 7 Hari Setelah Tanam (HST)

\begin{tabular}{cccccc}
\hline PP & Perlakuan & S0 & S1 & S2 & Rata-rata \\
\hline M0 & 5,394 & 4,972 & 5,128 & 5,165 \\
M1 & 4,500 & 5,383 & 4,983 & 4,955 \\
M2 & 4,911 & 4,906 & 5,244 & 5,020 \\
\hline Rata-rata & 4,935 & 5,087 & 5,118 & \\
\hline
\end{tabular}

Hasil tertinggi didapatkan pada perlakuan pemberian mulsa terhadap ratarata tinggi tanaman dihasilkan pada perlakuan mulsa (M0) yaitu $5,165 \mathrm{~cm}$, sedangkan yang terendah dihasilkan pada perlakuan mulsa dengan ketebalan $2 \mathrm{~cm}$ (M1) yaitu 4,955. Hal ini dipengaruhi oleh kedalaman penanaman kacang kedelai sehingga menghambat pertumbuhan tanaman.

Perlakuan pemberian pupuk kandang sapi terhadap rata-rata tinggi tanaman tertinggi diperoleh pada perlakuan pupuk kandang sapi $6 \mathrm{~kg} /$ petak (S2) yaitu $5,118 \mathrm{~cm}$, sedangkan yang terendah dihasilkan pada perlakuan tanpa pupuk kandang (S0) yaitu 4,935. Hal ini dikarenakan curah hujan yang tinggi pada saat aplikasi pupuk kandang sebelum penanaman diduga kandungan hara pupuk kandang sapi mengalami penguapan dan pencucian oleh air hujan.

\subsubsection{Tinggi Tanaman Umur 14 Hari Setelah Tanam (HST)}

Hasil sidik ragam pengaruh pemberian mulsa (M) dengan pupuk kandang sapi (S) serta interaksi kdua perlakuan berbeda tidak nyata terhadap tinggi tanaman kedelai umur 14 hari setelah tanam Tabel 3.

Tabel 3. Pengaruh Pemberian Mulsa dan Pupuk Kandang Sapi Terhadap Rata-rata Tinggi Tanaman Kacang Kedelai Umur 14 Hari Setelah Tanam (HST)

\begin{tabular}{cccccc}
\hline PP & Perlakuan & S0 & S1 & S2 & Rata-rata \\
\hline M0 & 9,244 & 8,500 & 8,350 & 8,698 \\
M1 & 8,183 & 8,583 & 8,011 & 8,592 \\
M2 & 8,939 & 8,330 & 8,050 & 8,773 \\
\hline Rata-rata & 8,789 & 8,471 & 8,804 & \\
\hline
\end{tabular}

Hasil tertinggi didapatkan pada perlakuan pemberian mulsa terhadap rata-rata tinggi tanaman diperoleh pada ketebalan mulsa $4 \mathrm{~cm}(\mathrm{M} 2)$ yaitu $8,773 \mathrm{~cm}$, sedangkan yang terendah pada perlakuan mulsa dengan ketebalan $2 \mathrm{~cm}$ (M1) yaitu $8,592 \mathrm{~cm}$. Pengaruh mulsa yang belum menunjukkan perbedaan nyata pada pertumbuhan tanaman kedelai. Hal ini dapat disebabkan oleh proses dekomposisi bahan mulsa belum sempurna dan kemungkinan lain ialah jumlah pemberian mulsa pada pertumbuhan kurang sehingga fungsi mulsa sebagai penahan proses penguapan menjadi kurang sempurna, dimana semakin tebal mulsa maka proses penguapan yang terjadi akan semakin kecil.

Hasil tertinggi didapatkan pada perlakuan pemberian pupuk kandang sapi terhadap rata-rata tinggi tanaman diperoleh pada perlakuan pupuk kandang sapi 6 $\mathrm{kg} /$ petak (S2) yaitu $8,804 \mathrm{~cm}$, sedangkan yang terendah pada perlakuan pupuk kandang $4 \mathrm{~kg} /$ petak (S1) yaitu 8,471. Hal ini dikarenakan curah hujan yang tinggi pada saat aplikasi pupuk kandang sebelum penanaman diduga kandungan hara pupuk kandang sapi mengalami pencucian oleh air hujan. 
3.1.3. Tinggi Tanaman Umur 21 Hari Setelah Tanam (HST)

Hasil sidik ragam pengaruh pemberian mulsa (M) dengan pupuk kandang sapi (S) serta interaksi kedua perlakuan berbeda tidak nyata terhadap tinggi tanaman kedelai umur 21 hari setelah tanam Tabel 4.

Tabel 4. Pengaruh Pemberian Mulsa dan Pupuk Kandang Sapi Terhadap Rata-rata Tinggi Tanaman Kacang Kedelai Umur 21 Hari Setelah Tanam (HST)

\begin{tabular}{cccccc}
\hline PP & Perlakuan & S0 & S1 & S2 & Rata-rata \\
\hline M0 & 12,128 & 10,856 & 11,505 & 11,496 \\
M1 & 10,611 & 11,678 & 11,539 & 11,276 \\
M2 & 11,750 & 10,634 & 11,861 & 11,415 \\
\hline Rata-rata & 11,496 & 11,056 & 11,635 & \\
\hline
\end{tabular}

Hasil tertinggi didapatkan pada perlakuan pemberian mulsa terhadap ratarata tinggi tanaman diperoleh pada tanpa perlakuan (M0) yaitu 11,496 cm, sedangkan yang terendah pada perlakuan mulsa dengan ketebalan $2 \mathrm{~cm}$ (M1) yaitu $11,276 \mathrm{~cm}$. Hal ini diduga disebabkan sewaktu penelitian berlangsung bertepatan dengan musim hujan. Curah hujan yang tinggi pada siang hari menyebabkan kelembaban dan temperatur tanah pada siang dan malam hari tidak jauh berbeda yang mengakibatkan pengaruh pada tinggi tanaman. Akibatnya peranan mulsa sebagai pengatur kelembaban dan suhu tanah tidak menunjukkan peranan yang maksimal.

Hasil tertinggi didapatkan pada perlakuan pemberian pupuk kandang sapi terhadap rata-rata tinggi tanaman diperoleh pada perlakuan pupuk kandang sapi $6 \mathrm{~kg} /$ petak $(\mathrm{S} 2)$ yaitu $11,635 \mathrm{~cm}$, sedangkan yang terendah pada perlakuan pupuk kandang $4 \mathrm{~kg} /$ petak (S1) yaitu 11,496. Hal ini dikarenakan curah hujan yang tinggi pada saat aplikasi pupuk kandang sebelum penanaman diduga kandungan hara pupuk kandang sapi mengalami penguapan dan pencucian oleh air hujan, sehingga diduga unsur hara yang terkandyng dalam pupuk kandang ayam menjadi berkurang. Hal ini sesuai dengan pernyataan Musnawar (2003) yang menyatakan bahwa kandungan unsur hara pupuk kandang dapat hilang karena beberapa faktor , antara lain penguapan.

\subsection{Jumlah Cabang Tanaman Kacang Kedelai}

3.2.1.Jumlah Cabang Umur 14 Hari Setelah Tanam (HST)

Hasil perhitungan sidik ragam menunjukkan perlakuan mulsa (M) berbeda nyata terhadap jumlah cabang tanaman kedelai umur 14 Hari sebelum tanam, sedangkan pada perlakuan pupuk kandang sapi (S) serta interaksi kedua perlakuan berbeda tidak nyata terhadap rata-rata jumlah cabang tanaman kedelai umur 14 hari setelah tanam Tabel 5. 
Tabel 5. Pengaruh Pemberian Mulsa dan Pupuk Kandang Sapi Terhadap Rata-rata Jumlah Cabang Tanaman Kacang Kedelai Umur 14 Hari Setelah Tanam

\begin{tabular}{cccccc}
\hline PP & Perlakuan & S0 & S1 & S2 & Rata-rata \\
\hline M0 & 1,556 & 1,500 & 1,833 & 1,630 \\
M1 & 1,556 & 2,222 & 2,111 & 1,963 \\
M2 & 1,500 & 2,556 & 2,055 & 2,037 \\
\hline Rata-rata & $1,537 \mathrm{a}$ & $2,093 \mathrm{~b}$ & $2,000 \mathrm{~b}$ &
\end{tabular}

Keterangan : Angka rata-rata yang diikuti oleh huruf yang sama berarti berbeda tidak nyata berdasarkan uji BNT taraf $5 \%$

Hasil terbanyak didapatkan pada perlakuan pemberian mulsa terhadap ratarata jumlah cabang dihasilkan pada perlakuan mulsa dengan ketebalan $4 \mathrm{~cm}$ (M2) yaitu 2,037 cabang, sedangkan yang terendah dihasilkan pada perlakuan tanpa mulsa (M0) yaitu 1,630 cabang. Hal ini diduga karena jarak tanam yang terlalu rapat, pada jarak tanam yang lebar mampu memaksimalkan penyerapan unsur hara dan sinar matahari. Hal tersebut mengakibatkan proses fotosintesis berjalan lebih optimal sehingga cabang yang dihasilkan menjadi lebih banyak.

Berdasarkan hasil uji BNT taraf 5\% pengaruh perlakuan pupuk kandang sapi terhadap jumlah cabang menunjukkan bahwa S0 berbeda nyata dengan perlakuan S1 dan S2, tetapi perlakuan S1 tidak berbeda nyata dengan perlakuan S2.

Perlakuan pemberian pupuk kandang sapi terhadap rata-rata jumlah cabang terbanyak diperoleh pada perlakuan pupuk kandang sapi $4 \mathrm{~kg} /$ petak (S1) yaitu 2,093 cabang, sedangkan yang sedikit dihasilkan pada perlakuan tanpa pupuk kandang (S0) yaitu 1,537 cabang. Hal ini diduga berkaitan dengan peranan unsur hara terutama unsur nitrogen dimana unsur hara tersebut mengatur pertumbuhan tanaman terutama pada saat pertumbuhan memasuki fase vegetatif.

\subsubsection{Jumlah Cabang Umur 21 Hari Setelah Tanam (HST)}

Hasil perhitungan sidik ragam menunjukkan perlakuan mulsa (M) tidak berbeda nyata terhadap jumlah cabang tanaman kedelai umur 21 Hari setelah tanam, sedangkan pada perlakuan pupuk kandang sapi (S) menunjukkan berpengaruh sangat nyata serta interaksi kedua perlakuan berbeda tidak nyata terhadap rata-rata jumlah cabang tanaman kedelai umur 21 hari setelah tanam Tabel 6.

Tabel 6. Pengaruh Pemberian Mulsa dan Pupuk Kandang Sapi Terhadap Rataan Jumlah Cabang Tanaman Kacang Kedelai Umur 21 Hari Setelah Tanam

\begin{tabular}{cccccc}
\hline PP & Perlakuan & S0 & S1 & S2 & Rata-rata \\
\hline M0 & 3,167 & 3,611 & 4,389 & 3,722 \\
& M1 & 3,278 & 4,444 & 4,333 & 4,018 \\
& M2 & 3,444 & 5,222 & 4,444 & 4,370 \\
\hline Rata-rata & $3,296 \mathrm{a}$ & $4,426 \mathrm{~b}$ & $4,389 \mathrm{~b}$ & \\
\hline
\end{tabular}

Keterangan : Angka rata-rata yang diikuti oleh huruf yang sama berarti berbeda tidak nyata berdasarkan uji BNT taraf 5\% 
Hasil terbanyak didapatkan pada perlakuan pemberian mulsa terhadap ratarata jumlah cabang dihasilkan pada perlakuan mulsa dengan ketebalan $4 \mathrm{~cm}$ (M2) yaitu 4,370 cabang, sedangkan yang terendah dihasilkan pada perlakuan tanpa mulsa (M0) yaitu 3,722 cabang. Hal tersebut dapat disebabkan oleh proses dekomposisi bahan mulsa belum sempurna, terutama untuk mulsa jerami.

Berdasarkan hasil uji BNT taraf 5\% pengaruh perlakuan pupuk kandang sapi terhadap jumlah cabang menunjukkan bahwa S0 berbeda nyata dengan perlakuan S1 dan S2, tetapi perlakuan S1 tidak berbeda nyata dengan perlakuan S2.

Hasil terbanyak didapatkan pada perlakuan pemberian pupuk kandang sapi terhadap rata-rata jumlah cabang diperoleh pada perlakuan pupuk kandang sapi $4 \mathrm{~kg} /$ petak (S1) yaitu 4,426 cabang, sedangkan yang terendah dihasilkan pada tanpa perlakuan pupuk kandang (S0) yaitu 3,296 cabang. Hal ini diduga pupuk kandang sapi memberikan unsur hara yang cukup untuk pembentukan cabang tanaman kedelai umur 21 hari setelah tanam.

\subsection{Umur Berbunga Hari Setelah Tanam (HST)}

Hasil perhitungan sidik ragam menunjukkan perlakuan mulsa (M) berbeda nyata terhadap umur berbunga tanaman kedelai hari setelah tanam, sedangkan pada perlakuan pupuk kandang sapi (S) serta interaksi kedua perlakuan menunjukkan pengaruh berbeda tidak nyata terhadap umur berbunga tanaman kedelai hari setelah tanam Tabel 7.

Tabel 7. Pengaruh Pemberian Mulsa dan Pupuk Kandang Sapi Terhadap Rata-rata Umur Berbunga Tanaman Kacang Kedelai Hari Setelah Tanam (HST)

\begin{tabular}{cccccc}
\hline PP & Perlakuan & S0 & S1 & S2 & Rata-rata \\
\hline M0 & 38,000 & 38,000 & 38,000 & $38,000 \mathrm{a}$ \\
& M1 & 38,667 & 38,333 & 38,333 & $38,444 \mathrm{~b}$ \\
M2 & 38,667 & 38,000 & 38,000 & $38,222 \mathrm{ab}$ \\
\hline Rata-rata & 38,445 & 38,111 & 38,111 & \\
\hline
\end{tabular}

Keterangan : Angka rata-rata yang diikuti oleh huruf yang sama berarti berbeda tidak nyata berdasarkan uji BNT taraf 5\%

Berdasarkan hasil uji BNT taraf 5\% pengaruh perlakuan mulsa terhadap jumlah cabang menunjukkan bahwa M0 berbeda nyata dengan perlakuan M1 tetapi tidak berbeda nyata dengan perlakuan M2.

Hasil kecepatan berbunga didapatkan pada perlakuan mulsa terhadap rata-rata umur berbunga dihasilkan dengan ketebalan mulsa $2 \mathrm{~cm}$ (M1) yaitu 38,000 hari, sedangkan yang paling lama berbunga didapatkan pada perlakuan mulsa dengan ketebalan $2 \mathrm{~cm}$ (M0) yaitu 38,444 hari. Hal ini diduga karena umur tanaman berbunga dipengaruhi oleh suhu pada saat penanaman. Suprapto (2002) mengatakan umur berbunga sangat ditentukan suhu dan panjang hari, dimana semakin tinggi suhu maka semakin cepat berbunga.

Perlakuan pemberian pupuk kandang sapi terhadap rata-rata umur berbunga tercepat diperoleh pada perlakuan pupuk kandang sapi $4 \mathrm{~kg} /$ petak (S1) dan $6 \mathrm{~kg} /$ petak (S2) yaitu 38,111 hari, sedangkan yang paling lama berbunga dihasilkan pada perlakuan tanpa upuk kandang (S0) yaitu 38,445 hari. Hal ini dikarenakan kandungan unsur hara dalam tanah masih tersedia dan cukup untuk pembentukan bunga tanaman kedelai. 


\subsection{Umur Panen Hari Setelah Tanam}

(HST)

Hasil perhitungan sidik ragam menunjukkan perlakuan mulsa (M) serta interaksi kedua perlakuan menunjukkan berbeda tidak nyata terhadap umur panen tanaman kedelai hari setelah tanam, sedangkan pada perlakuan pupuk kandang sapi (S) menunjukkan berbeda sangat nyata terhadap umur panen tanaman kedelai hari setelah tanam Tabel 8.

Tabel 8. Pengaruh Pemberian Mulsa dan Pupuk Kandang Sapi Terhadap Rata-rata Umur Panen Tanaman Kacang Kedelai Hari Setelah Tanam (HST)

\begin{tabular}{cccccc}
\hline PP & Perlakuan & S0 & S1 & S2 & Rata-rata \\
\hline M0 & 92,000 & 91,000 & 91,333 & 91,444 \\
M1 & 91,667 & 91,000 & 91,000 & 91,222 \\
M2 & 91,667 & 91,000 & 91,000 & 91,222 \\
\hline Rata-rata & $91,778 \mathrm{~b}$ & $91,000 \mathrm{a}$ & $91,111 \mathrm{ab}$ & \\
\hline
\end{tabular}

Keterangan : Angka rata-rata yang diikuti oleh huruf yang sama berarti berbeda tidak nyata berdasarkan uji BNT taraf $5 \%$

Hasil kecepatan panen didapatkan pada perlakuan pemberian mulsa terhadap rata-rata umur panen dihasilkan pada perlakuan mulsa dengan ketebalan 2 cm (M1) dan $4 \mathrm{~cm}$ (M2) yaitu 91,222 hari, sedangkan yang lama berbunga dihasilkan pada perlakuan tanpa mulsa (M0) yaitu 91,444 hari. Hal ini diduga umur panen dipengaruhi oleh kebutuhan cahaya matahari yang kurang karena jarak tanam yang terlalu dekat mengakibatkan kebutuhan cahaya dan unsur hara tidak terpenuhi dengan seimbang.

Berdasarkan hasil uji BNT taraf 5\% pengaruh perlakuan pupuk kandang sapi terhadap umur panen menunjukkan bahwa S0 berbeda nyata dengan perlakuan S1 tetapi tidak berbeda nyata terhadap perlakuan S2.

Perlakuan pemberian pupuk kandang sapi terhadap rata-rata umur panen tercepat diperoleh pada perlakuan pupuk kandang sapi $4 \mathrm{~kg} /$ petak (S1) yaitu 91,000 hari, sedangkan yang paling lama panen didapatkan pada perlakuan tanpa pupuk kandang (S0) yaitu 91,778 hari. Diduga perlakuan pupuk kandang di atas $4 \mathrm{~kg} /$ petak menyebabkan unsur hara yang tersedia lebih dari cukup yang dibutuhkan tanaman kedelai.

\subsection{Jumlah Polong Isi}

Hasil perhitungan sidik ragam menunjukkan perlakuan mulsa (M) menunjukkan berbeda nyata terhadap jumlah polong isi tanaman kedelai, sedangka pada perlakuan pupuk kandang sapi (S) serta interaksi kedua perlakuan menunjukkan berbeda tidak nyata terhadap jumlah polong isi tanaman kedelai Tabel 9.

Tabel 9. Pengaruh Pemberian Mulsa dan Pupuk Kandang Sapi Terhadap Rata-rata Jumlah Polong Isi Tanaman Kacang Kedelai

\begin{tabular}{cccccc}
\hline PP & Perlakuan & S0 & S1 & S2 & Rata-rata \\
\hline & M0 & 95,722 & 110,389 & 110,611 & $105,574 \mathrm{a}$ \\
M1 & 11,389 & 122,778 & 116,111 & $116,426 \mathrm{ab}$ \\
M2 & 129,833 & 127,055 & 136,721 & $131,203 \mathrm{~b}$ \\
\hline Rata-rata & 111,981 & 120,074 & 121,148 & \\
\hline
\end{tabular}

Keterangan : Angka rata-rata yang diikuti oleh huruf yang sama berarti berbeda tidak nyata berdasarkan uji BNT taraf 5\% (17.098). 
Berdasarkan hasil uji BNT taraf 5\% pengaruh mulsa terhadap jumlah polong isi menunjukkan bahwa M0 berbeda tidak nyata pada perlakuan M1 tetapi berbeda nyata pada perlkauan M2.

Hasil polong terbanyak didapatkan pada perlakuan pemberian mulsa terhadap rata-rata jumlah polong isi dihasilkan pada perlakuan mulsa dengan ketebalan $4 \mathrm{~cm}$ (M2) yaitu 131,203 polong, sedangkan hasil terendah dihasilkan pada perlakuan tanpa mulsa (M0) yaitu 105,574 polong. Hal ini diduga pada mulsa mampu mempengaruhi jumlah polong pada tanaman. Menurut dkk (2005) pertumbuhan tanaman yang baik akan meningkatkan proses fotosinteis serta menghasilkan fotosintat yang ditranslokasikan untuk pembentukan polong dan pengisian biji.

$$
\text { Perlakuan pemberian pupuk }
$$
kandang sapi terhadap rata-rata jumlah polong tanaman terbanyak diperoleh pada perlakuan pupuk kandang sapi $6 \mathrm{~kg} /$ petak (S2) yaitu 121,148 polong, sedangkan hasil terendah pada perlakuan tanpa pupuk kandang (S0) yaitu 111,981 polong. Hal ini diduga karena polong pada tanaman kedelai sangat dipengaruhi oleh faktor lingkungan yang dalam hal ini adalah jenis dan dosis pupuk yang diberikan yaitu unsur hara $\mathrm{N}, \mathrm{P}$, dan $\mathrm{K}$ yang terkandung dalam pupuk kotoran sapi dan kotoran ayam yang sudah matang yang memperbaiki sifat fisik, kimia, dan biologi tanah.

\subsection{Berat Biji/Petak}

Hasil perhitungan sidik ragam menunjukkan perlakuan mulsa (M) menunjukkan berbeda sangat nyata terhadap berat biji/petak tanaman kedelai, sedangka pada perlakuan pupuk kandang sapi (S) serta interaksi kedua perlakuan menunjukkan berbeda tidak nyata terhadap berat biji/petak tanaman kedelai Tabel 10

Tabel 10. Pengaruh Pemberian Mulsa dan Pupuk Kandang Sapi Terhadap Rata-rata Berat Biji/Petak Tanaman Kacang Kedelai

\begin{tabular}{cccccc}
\hline PP & Perlakuan & S0 & S1 & S2 & Rata-rata \\
\hline M0 & 200,667 & 207,333 & 234,333 & $214,111 \mathrm{a}$ \\
M1 & 229,000 & 297,667 & 234,333 & $253,667 \mathrm{ab}$ \\
M2 & 267,333 & 304,000 & 312,333 & $294,555 \mathrm{~b}$ \\
\hline Rata-rata & 232,333 & 269,667 & 260,333 & \\
\hline
\end{tabular}

Keterangan : Angka rata-rata yang diikuti oleh huruf yang sama berarti berbeda tidak nyata berdasarkan uji BNT taraf $5 \%$

Berdasarkan hasil uji BNT taraf 5\% pengaruh mulsa terhadap berat biji/petak menunjukkan bahwa M0 tidak berbeda nyata pada perlakuan M1 tetapi berbeda nyata pada perlakuan M2.

Hasil terbanyak didapatkan pada perlakuan pemberian mulsa terhadap rata-rata berat biji/petak dihasilkan pada perlakuan mulsa dengan ketebalan $4 \mathrm{~cm}$ (M2) yaitu 294,555 gram, sedangkan hasil terendah didapatkan pada perlakuan tanpa mulsa (M0) yaitu 214,111 gram. Hal ini membuktikan bahwa tanaman kedelai mengalami kompetisi dengan gulma yang tumbuh.

Perlakuan pemberian pupuk kandang sapi terhadap rata-rata berat biji/petak terbanyak diperoleh pada perlakuan pupuk kandang sapi $4 \mathrm{~kg} /$ petak (S1) yaitu 269,667, sedangkan hasil terendah pada perlakuan tanpa pupuk kandang (S0) yaitu 232,333. Hal ini diduga karena kebutuhan air tidak terpenuhi untuk tanaman kedelai. 


\subsection{Produktifitas Ton/Ha}

Hasil perhitungan sidik ragam menunjukkan perlakuan mulsa (M) menunjukkan berbeda sangat nyata terhadap produktifitas tanaman kedelai, sedangka pada perlakuan pupuk kandang sapi (S) serta interaksi kedua perlakuan menunjukkan berbeda tidak nyata terhadap produktifitas tanaman kedelai Tabel 11.

Tabel 11. Pengaruh Pemberian Mulsa dan Pupuk Kandang Sapi Terhadap Rata - rata Produktifitas Tanaman Kacang Kedelai (Ton/Ha)

\begin{tabular}{cccccc}
\hline PP & Perlakuan & S0 & S1 & S2 & Rata-rata \\
\hline & M0 & 0,444 & 0,691 & 0,781 & $0,639 \mathrm{a}$ \\
M1 & 0,763 & 0,992 & 0,781 & $0,846 \mathrm{~b}$ \\
& M2 & 0,921 & 1,013 & 1,041 & $0,992 \mathrm{~b}$ \\
\hline Rata-rata & 0,709 & 0,899 & 0,868 & \\
\hline
\end{tabular}

Keterangan : Angka rata-rata yang diikuti oleh huruf yang sama berarti berbeda tidak nyata berdasarkan uji BNT taraf 5\%

Berdasarkan hasil uji BNT taraf 5\% pengaruh mulsa terhadap produktifitas tanaman menunjukkan bahwa M0 berbeda nyata pada perlakuan M1 dan M2, tetapi perlakuan M1 berbeda tidak nyata terhadap perlakuan M2.

Hasil tertinggi didapatkan pada perlakuan pemberian mulsa dengan ketebalan $4 \mathrm{~cm}$ (M2) yaitu 0,992, sedangkan hasil terendah dihasilkan pada perlakuan tanpa mulsa (M0) yaitu 0,639. Hasil sidik ragam perlakuan pemberian mulsa berbeda sangat nyata. Hal ini dikarenakan kelembaban tanah tinggi serta mempunyai tekstur lebih kecil dan dapat tersebar merata menutupi permukaan tanah.

Perlakuan pemberian pupuk kandang sapi terhadap rata-rata produksi ton/ha diperoleh pada perlakuan pupuk kandang sapi $4 \mathrm{~kg} /$ petak (S1) yaitu 0,899, sedangkan hasil terendah pada perlakuan tanpa pupuk kandang (S0) yaitu 0,709.

\subsection{Interaksi Antara Perlakuan Mulsa Dan Pupuk Kandang Sapi}

Hasil sidik ragam interaksi antara perlakuan mulsa dan pupuk kandang sapi berpengaruh tidak nyata terhadap ratarata tinggi tanaman umur 7 hst, 14 hst, dan 21 hst, kemudian berpengaruh tidak nyata terhadap rata-rata jumlah cabang umur 14 hst dan 21 hst, umur berbunga pada perlakuan M1S1, M1S2, M2S1 dan M2S2, umur panen pada perlakuan M1S1, M1S2, M2S1 dan M2S2, jumlah polong isi pada perlakuan M1S1, M1S2, berat biji/petak pada perlakuan M2S1, M2S2, dan produktifitas ton/ha pada perlakuan M1S1, M1S2.

Hal ini diduga pada masing-masing perlakuan tidak saling menopang dalam mempengaruhi pertumbuhan tanaman kedelai sehingga menimbulkan pengaruh tidak nyata, pengaruh tidak nyata menunjukkan masing-masing perlakuan berdiri sendiri-sendiri. Hal ini sesuai dengan pendapat Hanafia (2010) menyatakan bahwa jika terdapat pengaruh interaksi yang signifikan maka kedua faktor perlakuan saling mempengaruhi atau tidak terpisahkan, sedangkan jika tidak terpisahkan interaksi berarti masing-masing perlakuan tidak saling mempengaruhi.

\section{KESIMPULAN}

Berdasarkan hasil penelitian pengaruh Mulsa dan Pupuk Kandang Sapi Terhadap Pertumbuhan dan Hasil Tanaman Kedelai (Glycine max (L.) Merril) Pada Lahan Pasang Surut, maka diambil kesimpulan sebagai berikut: Perlakuan mulsa berpengaruh nyata terhadap rata-rata tinggi tanaman umur 7 
Hst, 14 Hst, 21 Hst, jumlah cabang umur 14 Hst, 21 Hst, dan umur panen, tetapi tidak berpengaruh nyata terhadap umur berbunga, jumlah polong isi, berat biji/petak, dan produktifitas tanaman. Perlakuan mulsa dengan ketebalan $4 \mathrm{~cm}$ (M2) memberikan hasil terbaik.

Pemberian pupuk kandang sapi berpengaruh tidak nyata terhadap tinggi tanaman umur $7 \mathrm{Hst}, 14 \mathrm{Hst}, 21 \mathrm{Hst}$, umur berbunga, jumlah polong isi, berat biji/petak, dan produktifitas tanaman, tetapi berpengaruh nyata terhadap jumlah cabang umur $14 \mathrm{Hst}, 21 \mathrm{Hst}$, dan umur panen. Pemberian pupuk kandang sapi dengan perlakuan $4 \mathrm{~kg} /$ petak memberikan hasil yang terbaik pada tanaman kedelai.

Interaksi perlakuan berpengaruh tidak nyata terhadap tinggi tanaman, jumlah cabang, umur berbunga, umur panen, jumlah polong isi, berat biji/petak, produktifitas tanaman kedelai. Hasil penelitian menunjukkan bahwa pertumbuhan dan hasil tanaman kedelai yang terbaik pada tanaman pada kombinasi perlakuan (M2S2).

\section{DAFTAR PUSTAKA}

Abdurahman. (2005). Teknik Pemberian Pupuk Organik dan Mulsa pada Budidaya Mentimun Jepang. Buletin Teknik Pertanian, Juli 2005. 10 (2): 53 - 56.

Adisarwanto, R. (2005). Meningkatkan Hasil Panen Kedelai di Lahan Sawah Kering Pasang Surut. Penerbit Swadaya.

Adimihardja, A., I. Juarsah, dan U. Kurnia. (2000). Pengaruh Penggunaan Berbagai Jenis Pupuk Kandang Terhadap Produktifitas Tanah Ultisols Terdegradasi di Desa Batin, Jambi. Hal 303-319 dalam Prosiding. Seminar Nasional Sumber Daya Tanah, Iklim dan
Pupuk. Buku II. Lido-Bogor, 6-8 Des. 1999. Pusat Penelitian Tanah dan Agroklimat, Bogor.

Andrianto, I. (2004). Teknologi Budidaya Intensif Tanaman Kedelai di Lahan Sawah. Jurnal Proyek Penelitian dan Pengembangan Pertanian Rawa Terpadu 17(1): 1-8

Arsyad, D.M. dan M. Syam. (1998). Kedelai. Sumber Pertumbuhan produksi dan Teknik Budidaya. Edisi Revisi. Puslitbangtan. 30 hlm.

Barus, W. A. (2004). Respon pertumbuhan dan hasil tanaman kedelai yang ditumpangsarikan dengan jagung terhadap pengaturan saat tanam dan jarak tanam.

Http://Repository.Usu.Ac.Id/Bitstre am/123456789/15513/1/ KptDes2004-\%20(2). Pdf. Diakses tanggal 26 Januari 2017.

Bertham, Y. H. (2002). Respon Tanaman Kedelai [Glycine max (L.) Merrill] Terhadap Pemupukan Fosfor Dan Kompos Jerami Di Tanah Ultisol. JIPI, 4(2), 78-83.

Fuad, T. (2013). Pertumbuhan dan hasil tanaman kedelai (Glycine max L. Merrill) berdasarkan variasi mulsa dan jarak tanam. kim.ung.ac.id/index.php/KIMFIIP/a rticle/download/2468/2447. Diakses pada 26 Januari 2017.

Hidayat, O. (1985). Morfologi Tanaman Kedelai pada Lahan Kering. Badan Penelitian dan Perkembangan Pertanian. Pusat Penelitian dan Perkembangan Tanaman Pangan. Bogor.

Irwan, W.A. (2006). Budidaya Tanaman Kedelai (Glycine max (L.) Merill). Universitas Padjajaran: Jatinangor 
Lakitan, B. (1995). Hortikultura I, Teori Budidaya dan Pasca Panen. Jakarta: Raja Grafindo Persada.

Musnawar, E.I. (2005). Pupuk Orga-nik Cair dan Padat, Pembuatan dan Cara Aplikasi. Jakarta: Penebar Swadaya.

Musnawar, E. I. (2003). Pupuk organic padat : pembuatan dan aplikasi. Jakarta: Penebar Swadaya.

Salisbury, F. B. dan C. W. Ross. (1995). Fisiologi Tumbuhan. Jilid I. Edisi IV. Bandung: ITB.
Soeprapto. (2002). Cara Bercocok Tanam Kedelai. Jakarta: Penebar Swadaya.

Sumarno. (1987). Kedelai dan Cara Budidaya. Bogor: Yasaguna Bogor.

Suprapto. (1997). Bertanam Kedelai. Jakarta: PT. Penebar Swadaya.

Tamaluddin. (1993). Peranan Mulsa dalam Mencegah Degradasi Lahan. Bandar Lampung: Universitas Lampung. 